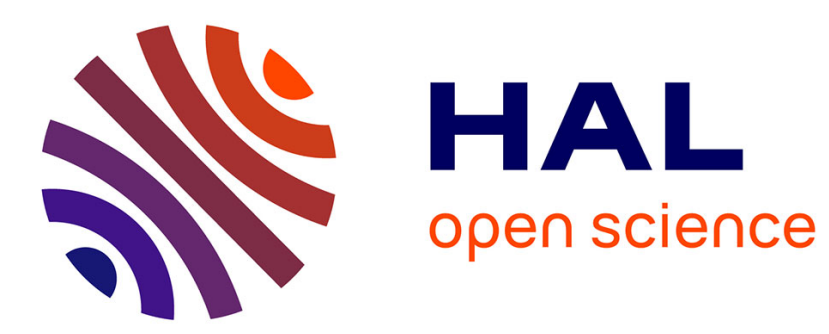

\title{
Nitrate leaching is not controlled by the slurry application technique in productive grassland on organic-sandy soil
}

Manfred Kayser, Laura Breitsameter, Matthias Benke, Johannes Isselstein

\section{- To cite this version:}

Manfred Kayser, Laura Breitsameter, Matthias Benke, Johannes Isselstein. Nitrate leaching is not controlled by the slurry application technique in productive grassland on organic-sandy soil. Agronomy for Sustainable Development, 2015, 35 (1), pp.213-223. 10.1007/s13593-014-0220-y . hal-01284249

\author{
HAL Id: hal-01284249 \\ https://hal.science/hal-01284249
}

Submitted on 7 Mar 2016

HAL is a multi-disciplinary open access archive for the deposit and dissemination of scientific research documents, whether they are published or not. The documents may come from teaching and research institutions in France or abroad, or from public or private research centers.
L'archive ouverte pluridisciplinaire HAL, est destinée au dépôt et à la diffusion de documents scientifiques de niveau recherche, publiés ou non, émanant des établissements d'enseignement et de recherche français ou étrangers, des laboratoires publics ou privés. 


\title{
Nitrate leaching is not controlled by the slurry application technique in productive grassland on organic-sandy soil
}

\author{
Manfred Kayser • Laura Breitsameter • Matthias Benke • \\ Johannes Isselstein
}

Accepted: 3 March 2014 / Published online: 25 April 2014

(C) INRA and Springer-Verlag France 2014

\begin{abstract}
The return of slurry is the most important means of fertilization in grassland dairy farming. Broadcast application of slurry induces air pollution by ammonia. Alternatives to broadcast application like sliding shoe or injection have therefore been introduced. These alternatives might, however, cause higher $\mathrm{N}$ losses by nitrate leaching because $\mathrm{N}$ prevented from volatilization may not completely be utilized for dry matter production. Information on the interactive effects of amount of $\mathrm{N}$ input and slurry application technique on nitrate leaching from productive organic-sandy soils are still scarce. Therefore, we tested the hypothesis that slurry application by sliding shoe or injection leads to larger $\mathrm{NO}_{3}-\mathrm{N}$ losses via leaching than broadcast application. In a 4-year experiment on cut grassland, we applied $\mathrm{N}$ at $0,160,240$, and $320 \mathrm{~kg} \mathrm{ha}^{-1}$ year $^{-1}$ using four application techniques: in the form of a chemical-synthetic $\mathrm{N}$ fertilizer or as cattle slurry applied broadcast, by sliding shoe or shallow injection. We assessed nitrate leaching during winter using suction cups. Additionally, we determined herbage dry matter yields, $\mathrm{N}$ offtake, and soil mineral $\mathrm{N}$ content to compile $\mathrm{N}$ balances for the individual treatments based on these data. Our results show that nitrate leaching during winter did not differ
\end{abstract}

\footnotetext{
M. Kayser $(\square)$

Department of Crop Sciences, Grassland Science,

Georg-August-University Göttingen, Location Vechta,

Driverstraße 22, 49377 Vechta, Germany

e-mail: manfred.kayser@agr.uni-goettingen.de

L. Breitsameter $\cdot$ J. Isselstein

Department of Crop Sciences, Grassland Science,

Georg-August-University Göttingen, Von-Siebold-Strasse 8,

37075 Göttingen, Germany

M. Benke

Chamber of Agriculture Lower-Saxony, Mars-la-Tour-Straße 1-13, 26121 Oldenburg, Germany
}

significantly among treatments of $\mathrm{N}$ application technique. Nitrate leaching increased significantly with increasing amount of $\mathrm{N}$ input, but was on average lower than $16.5 \mathrm{~kg} \mathrm{~N} \mathrm{ha}^{-1}$ for application rates of up to $320 \mathrm{~kg} \mathrm{~N} \mathrm{ha}^{-1}$. Soil mineral $\mathrm{N}$ content in autumn was a reasonably good predictor for nitrate leaching, with $R^{2}$ of 0.65 . The proportion of nitrate leaching of positive $\mathrm{N}$ surpluses increased in the order broadcast, sliding shoe, injection, and chemicalsynthetic $\mathrm{N}$ application. Our findings demonstrate that the amount of $\mathrm{N}$ input but not the technique of application results in a significant effect on nitrate leaching.

Keywords Slurry injection · Sliding shoe application · Yield · Apparent nitrogen recovery $\cdot$ Soil mineral nitrogen content $\cdot$ Calcium ammonium nitrate

\section{Introduction}

In north-western Europe, there has been a continuing trend towards the concentration of dairy farming in grasslanddominated regions (Osterburg et al. 2010; Smit et al. 2008). On cattle farms, the return of manures, often in the form of slurry, is the most important way of supplying nutrients to grasslands.

For reasons of water protection, annual $\mathrm{N}$ returns in manures are restricted to $170 \mathrm{~kg} \mathrm{~N} \mathrm{ha}^{-1}$ (European Union Nitrates Directive, 91/676/EEC1). However, in regions with high livestock densities, slurry production per hectare pastureland greatly exceeds this value. Therefore, an extension of up to $250 \mathrm{~kg} \mathrm{~N} \mathrm{ha}^{-1}$ is being discussed for grassland and in some cases granted as a derogation. Generally, mown grassland shows leaching of merely $2-10 \%$ of the $\mathrm{N}$ applied up to fertilizer application rates of $250 \mathrm{~kg} \mathrm{~N} \mathrm{ha}^{-1}$ (Garwood and Ryden 1986; Schröder et al. 2010), and leaching losses from slurry application on mown grassland are not necessarily 
higher than those from chemical-synthetic fertilizer under similar conditions (Benke 1992; Jarvis et al. 1987).

There are some general implications with slurry application: cattle slurry comprises $\mathrm{N}$ in organic and in inorganic form, mainly as ammonium, to almost equal proportions. The ammoniacal $\mathrm{N}$ is readily available for plant uptake but susceptible to ammonia volatilization and/or denitrification (Bussink and Oenema 1998; Whitehead 1995; Garwood and Ryden 1986). Only a proportion of the organic form is mineralized in the year of application, but regular applications may produce a cumulative effect on the amount of $\mathrm{N}$ mineralized during successive years (Gutser et al. 2005; Schröder et al. 2005).

To reduce gaseous losses after application of cattle slurry, application techniques like sliding shoe and injection have been introduced as alternatives to broadcast application (Misselbrook et al. 2002; Javis and Pain 1997). These techniques should provide potential for improving the $\mathrm{N}$ use efficiency. However, they might also increase the risk of nitrate leaching as $\mathrm{N}$ prevented from volatilization may not completely be utilized for dry matter production.

Nitrate leaching is influenced by many factors including the amount and the type of fertilizer applied, the soil type, water regime, sward age, and weather. On free-draining sandy soils, apart from gaseous losses immediately after application, leaching during winter is the most important pathway for nutrient losses, while denitrification plays a minor role (Whitehead 1995). On productive, sandy soils with a relatively high content of organic matter and a high mineralization potential, however, little is known about the effect of different slurry application techniques on nitrate leaching.

In this paper, we follow the hypothesis that in productive grasslands on organic-sandy soils slurry application techniques that reduce gaseous losses lead to larger leaching losses. To address this hypothesis, we conducted a 4-year experiment on cut grassland on an organic-sandy soil in northwest Germany.

\section{Materials and methods}

\subsection{Site}

The experimental site was located in the county of Cloppenburg, state of Lower-Saxony, northwest Germany $\left(52^{\circ} 56^{\prime} 44^{\prime \prime} \mathrm{N}, 7^{\circ} 50^{\prime} 17^{\prime \prime} \mathrm{E}\right)$. The original soil type can be described as a Gleyic Podzol (WRB) ( Typic Haplaquod, Soil Taxonomy) covered with a relatively shallow layer $(0-50 \mathrm{~cm})$ of degraded peat (high-moor) which had been converted into an Anthric Podzol (WRB) by deep-ploughing during the 1970s. The texture of the topsoil was sand to loamy sand with on average $87 \%$ sand ( $50 \%$ fine sand), $11 \%$ silt, and $2 \%$ clay and a dry bulk density of 1.41 ; volumetric water content at field capacity was on average $20.8 \%$. The groundwater level was at $150-200 \mathrm{~cm}$ depth. From 1975 to 1991 , the experimental site had been used as arable land with regular ploughing and input of organic fertilizer (120-160 kg total $\mathrm{N} \mathrm{ha}^{-1}$ ) which resulted in a distinct and entirely mixed topsoil with sufficient contents of the main plant available mineral nutrients of lactate-soluble $\mathrm{P}$ and $\mathrm{K}$ of 198 and $56 \mathrm{mg} \mathrm{kg}^{-1}$, respectively, and a $\mathrm{pH}\left(\mathrm{CaCl}_{2}\right)$ of 5.3. The average total $\mathrm{C}$ content was $2.7 \%$, the total $\mathrm{N}$ content $0.15 \%$, and $\mathrm{C} / \mathrm{N}$ ratio $18: 1(n=24,0-20 \mathrm{~cm})$.

In 1991, the site was sown with a standard grass mixture that did not contain white clover. The established sward consisted mainly of Lolium perenne and to a lesser extent of Phleum pratense, Festuca pratensis, Poa trivialis, Elymus repens, and Taraxacum officinale.

Meteorological data were obtained from a station of the German Weather Service (DWD) in Friesoythe-Altenoythe, which was within a $12 \mathrm{~km}$ range from the experimental site. Evapotranspiration was calculated following a procedure proposed by Haude (DVWK 1996). The 4-year-average for the period of May to April (long-term average in brackets) amounted to $730 \mathrm{~mm}(783 \mathrm{~mm})$ of precipitation, a mean daily temperature of $9.4^{\circ} \mathrm{C}\left(8.7^{\circ} \mathrm{C}\right)$, and $231 \mathrm{~mm}(265 \mathrm{~mm})$ of water leached from November to April. Apart from the second winter, which was exceptionally cool and dry (Table 1), winter seasons of the other years were relatively mild with average to high rainfall. In year 3, the summer was colder than in the other years and precipitation was below average except in August and October with above-average precipitation and several incidents of strong rainfall.

\subsection{Experimental design}

The experiment had a two-factorial split-plot design. The main factors were $\mathrm{N}$ application technique $(n=4: \mathrm{N}$ applied in the form of chemical-synthetic fertilizer, calcium ammonium nitrate, or as cattle slurry applied broadcast, by sliding shoe or by injection; whole plots) and the subordinate factor was $\mathrm{N}$ application rate $\left(n=4: 0,160,240\right.$, and $320 \mathrm{~kg} \mathrm{~N}^{-1}$; subplots). Treatments were repeated four times (block) and subplot size was $72 \mathrm{~m}^{2}$. Fresh cattle slurry was obtained from one dairy farm during the whole of the experiment. Slurry dry matter content was approx. $6 \%, \mathrm{~N}$ content was on average $3.4 \mathrm{~kg} \mathrm{~m}^{-3}$, and the average proportion of $\mathrm{NH}_{4}-\mathrm{N}$ in cattle slurry was $60 \%$ of the total $\mathrm{N}$ content. Total $\mathrm{N}$ content of slurry was determined prior to each application date and samples were later analyzed for $\mathrm{NH}_{4}$, $\mathrm{P}$, and $\mathrm{K}$. The experiment was conducted over a period of 4 years from 1994 to 1998; parts of the experiment were extended to 6 years. For comparison, some 6-year data are presented where appropriate. 
Table 1 Climate data of the four experimental years obtained from the station of German Weather Service (DWD) in FriesoytheAltenoythe

\begin{tabular}{|c|c|c|c|c|c|}
\hline & & $\begin{array}{l}\text { Period } \\
\text { May-July }\end{array}$ & Aug-Oct & Nov-Jan & Feb-April \\
\hline \multirow[t]{6}{*}{ Temperature $\left[{ }^{\circ} \mathrm{C}\right]$} & Year 1 & 16.2 & 12.9 & 5.0 & 6.0 \\
\hline & Year 2 & 15.5 & 14.8 & 0.4 & 3.2 \\
\hline & Year 3 & 14.0 & 13.3 & 1.1 & 6.3 \\
\hline & Year 4 & 15.7 & 14.3 & 4.4 & 7.3 \\
\hline & Mean & 15.3 & 13.8 & 2.7 & 5.7 \\
\hline & 100 -year mean & 14.7 & 13.2 & 2.8 & 4.3 \\
\hline \multirow[t]{6}{*}{ Precipitation sum [mm] } & Year 1 & 199.8 & 286.5 & 246.8 & 225.9 \\
\hline & Year 2 & 223.7 & 172.6 & 84.5 & 61.5 \\
\hline & Year 3 & 161.8 & 263.2 & 132.5 & 158.1 \\
\hline & Year 4 & 245.5 & 98.8 & 167.8 & 192.4 \\
\hline & Mean & 207.7 & 205.3 & 157.9 & 159.5 \\
\hline & 100 -year mean & 209.5 & 198.6 & 216.5 & 158.5 \\
\hline \multirow[t]{6}{*}{ Evapotranspiration sum [mm] } & Year 1 & 266.6 & 145.7 & 30.1 & 86.5 \\
\hline & Year 2 & 252.3 & 201.6 & 25.7 & 117.9 \\
\hline & Year 3 & 212.7 & 180.1 & 23.7 & 97.2 \\
\hline & Year 4 & 263.9 & 218.6 & 29.5 & 93.8 \\
\hline & Mean & 248.9 & 186.5 & 27.3 & 98.9 \\
\hline & 100 -year mean & 227.9 & 151.4 & 26.2 & 84.5 \\
\hline \multirow{5}{*}{$\begin{array}{l}\text { Estimated leaching in winter } \\
\text { (November to April) [mm] }\end{array}$} & Year 1 & & & 410.2 & \\
\hline & Year 2 & & & 66.3 & \\
\hline & Year 3 & & & 216.4 & \\
\hline & Year 4 & & & 231.9 & \\
\hline & Mean & & & 231.2 & \\
\hline
\end{tabular}

\subsection{Chemical-synthetic $\mathrm{N}$ fertilizer and slurry application}

In both the treatments receiving chemical-synthetic $\mathrm{N}$ fertilizer (calcium ammonium nitrate) and those receiving slurry, the annual total $\mathrm{N}$ fertilization was applied in multiple doses of $80 \mathrm{~kg} \mathrm{~N} \mathrm{ha}^{-1}$. For $320 \mathrm{~kg} \mathrm{~N} \mathrm{ha}^{-1}$ (N320), a total of four applications were made: the first one in early spring (March) and additionally one application each after the first, second, and third cut; for $240 \mathrm{~kg} \mathrm{~N}^{-1}$ (N240) and $160 \mathrm{~kg} \mathrm{~N}^{-1}$ (N160), applications were made in spring, after the first and second cut, and in spring and after the first cut, respectively.

Every year, $\mathrm{P}$ and $\mathrm{K}$ were added in mineral form to the plots that did not receive $\mathrm{N}$ fertilization (N0) and to those that received $\mathrm{N}$ as calcium ammonium nitrate $(\mathrm{CAN})$. All $\mathrm{N} 0$ plots received $166 \mathrm{~kg} \mathrm{~K}^{-1}$ and $24 \mathrm{~kg} \mathrm{P} \mathrm{ha}^{-1}$ in mineral form as $\mathrm{KCl}$ or triplephosphate; this was the case for CAN160 as well; CAN240 and CAN320 received $300 \mathrm{~kg} \mathrm{~K} \mathrm{ha}^{-1}$ and $48 \mathrm{~kg} \mathrm{P}$ $\mathrm{ha}^{-1}$ in two dressings. For the plots receiving slurry treatments, the cattle slurry applied as $\mathrm{N}$ fertilizer was also the source of $\mathrm{P}$ and $\mathrm{K}$. Inputs of $\mathrm{K}$ and $\mathrm{P}$ with cattle slurry amounted on average to $213 \mathrm{~kg} \mathrm{~K} \mathrm{ha}^{-1}$ and $38 \mathrm{~kg} \mathrm{P}^{-1}$, to $320 \mathrm{~kg} \mathrm{~K} \mathrm{ha}^{-1}$ and $57 \mathrm{~kg} \mathrm{P} \mathrm{ha}^{-1}$, and to $426 \mathrm{~kg} \mathrm{~K} \mathrm{ha}^{-1}$ and $76 \mathrm{~kg} \mathrm{P}$ ha $^{-1}$ for N160, N240, and N320, respectively.
Cattle slurry was applied broadcast by splash plate, by sliding shoe, or by open slot shallow injection (depth max. $5 \mathrm{~cm}$ ) with a tractor-attached experimental device that comprised application parts from slurry tanks used in practice (Fig. 1). Chemical-synthetic $\mathrm{N}$ fertilizer was applied broadcast

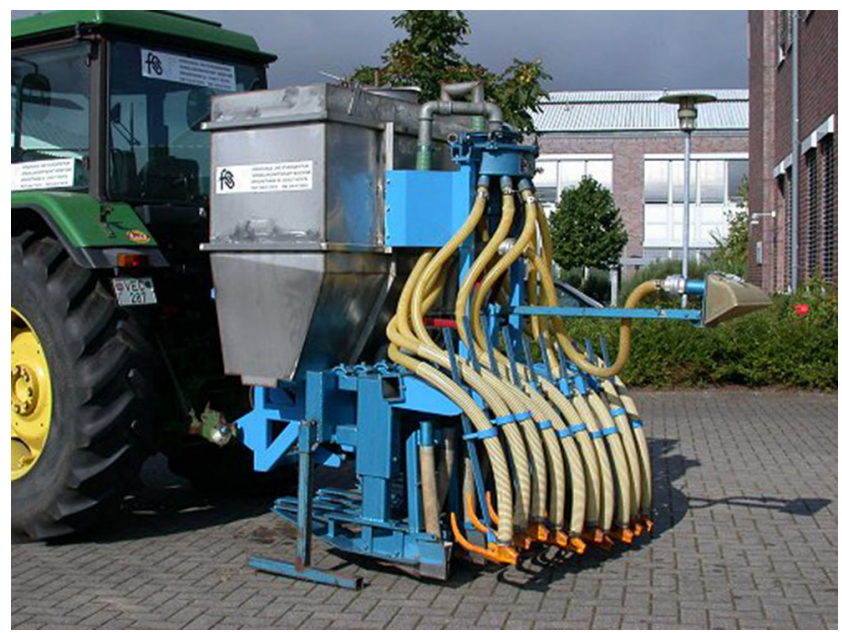

Fig. 1 A tractor-attached experimental device for slurry application that comprises application parts from slurry tanks used in practice 
by a pneumatic fertilizer spreader. On the N0 plots, the same machinery operations (trafficking, injection slits) were performed at three of the maximum four treatment dates, but no fertilization was applied.

\subsection{Sampling}

The sward at the experimental site was mown four times per year and herbage dry matter yield was determined from an area of $10 \mathrm{~m}^{2}$ per subplot. Herbage was oven-dried at $60{ }^{\circ} \mathrm{C}$ after sampling, ground to $<1 \mathrm{~mm}$, and analyzed for dry matter content at $105{ }^{\circ} \mathrm{C}$. Total $\mathrm{N}$ content of plant material was determined using an automated $\mathrm{N}$ analyzer macro $\mathrm{N}$ (Heraeus). Nitrogen offtake was calculated from dry matter yield and total $\mathrm{N}$ content of herbage.

Soil $\mathrm{P}$ and $\mathrm{K}$ content were quantified by extraction from soil samples following the double lactate method which uses $0.02 \mathrm{M} \mathrm{Ca}$ lactate and $0.02 \mathrm{M} \mathrm{HCl}(\mathrm{pH}$ 3.6) for extraction from $5 \mathrm{~g}$ dry soil. The filtered extracts were analyzed for $\mathrm{P}$ with an EPOS 5060 autoanalyzer (Eppendorf, Hamburg, Germany) and for $\mathrm{K}$ with an atomic absorption spectrometer (AAS, Varian SpectrAA300). Soil $\mathrm{pH}$ was determined in a $0.01 \mathrm{M} \mathrm{CaCl}_{2}$ solution, total $\mathrm{C}$ content by means of an infrared-cell in a LECO SC 444 analyzer (Leco Ltd.), and total $\mathrm{N}$ content was analyzed by an automated $\mathrm{N}$ analyzer macro N (Heraeus). All subplots were sampled in autumn and spring of each year to assess the soil mineral $\mathrm{N}$ content in 0 $90 \mathrm{~cm}$ : three to four soil cores per subplot in layers of $30 \mathrm{~cm}$ were bulked to give one sample per layer and subplot. For soil mineral $\mathrm{N}$ content determination, $\mathrm{NO}_{3}$ and $\mathrm{NH}_{4}$ were extracted from a 150-g soil sample with $600 \mathrm{~mL}$ of $0.0125 \mathrm{M} \mathrm{L}^{-1}$ $\mathrm{CaCl}_{2}$. Filtered extracts were analyzed for $\mathrm{NO}_{3}-\mathrm{N}$ and $\mathrm{NH}_{4}-\mathrm{N}$ photometrically with an EPOS 5060 autoanalyzer.

A permanent vacuum-controlled suction cup system with three cups per subplot was installed at $75 \mathrm{~cm}$ depth in every subplot to sample leaching water during winter. The suction pipes connecting the suction cups and sampling bottles were laid about $20 \mathrm{~cm}$ below ground and allowed unrestricted field management including slurry injection. Water from suction cups was continuously collected and stored until sampling in $1 \mathrm{~L}$ brown bottles placed in closed crates below the soil surface. Samples for laboratory analysis were collected from each bottle weekly or fortnightly during the leaching period from approximately mid-October to end of April. A permanent suction of $0.25-0.35$ bar was applied by a pressurecontrolled vacuum pump. This relatively low suction was chosen to avoid changes in the soil structure and hydrology near the suction cups.

Nitrate leaching was calculated as the product of the $\mathrm{NO}_{3}$ $\mathrm{N}$ concentration in the samples from suction cups and the amount of water percolating through the profile at a given time. We assumed that after the soil water content had reached field capacity in autumn, daily drainage equaled precipitation minus potential evapotranspiration (DVWK 1996). The sum of the $\mathrm{NO}_{3}-\mathrm{N}$ leaching for all sample dates while percolation occurred gave a total $\mathrm{NO}_{3}-\mathrm{N}$ loss over winter.

The apparent $\mathrm{N}$ recovery was calculated as

$\left(\mathrm{N}\right.$ offtake $_{\mathrm{Nx}}-\mathrm{N}$ offtake $\left.\mathrm{N0}\right) / \mathrm{N}$ applied $\times 100$

with $\mathrm{N}$ offtake being the $\mathrm{N}$ content of herbage $\times$ herbage dry matter yield at the respective level of annual $\mathrm{N}$ application rate $(\mathrm{Nx})$ and in the subplot receiving no $\mathrm{N}$ fertilization (N0). The $\mathrm{N}$ fertilizer replacement value of slurries was calculated as the ratio of the apparent $\mathrm{N}$ recovery of slurry to that of chemicalsynthetic fertilizer. Effective surplus was calculated following Schröder et al. (2010) as

( $\mathrm{N}$ applied with chemical-synthetic fertilizer $\times 1.0)-\mathrm{N}$ offtake with biomass

or as

$(\mathrm{N}$ applied as slurry $\times \mathrm{N}$ fertilizer replacement value) - N offtake with biomass

Plots with $\mathrm{N}$ application in the form of chemical-synthetic fertilizer and with cattle slurry applied by sliding shoe were maintained and sampled for 6 years in total and the results then used to supplement the calculation of apparent $\mathrm{N}$ recovery.

\subsection{Statistical analyses}

Statistical data analysis was carried out using the Genstat 6.2 software package. Analysis of variance (ANOVA) considered two factors in a split-plot design with four replications. To consider the effect of four consecutive experimental years, we applied the procedure "Arepmeasure" in Genstat which can be used to generate an ANOVA for repeated measurements, estimating and applying an adjustment factor for the degrees of freedom (Payne 2002). The error term was devised to represent the hierarchical experimental design with nested random effects of block, main plot, subplot, and year. Year was included in the ANOVA as a fixed effect. The following $d f$ (degree of freedom) correction factors for time were applied in ANOVA of the individual response variables: 0.9576 for dry matter yield, 0.7438 for $\mathrm{N}$ offtake, 0.8523 for soil mineral $\mathrm{N}$ content, and 0.8124 for nitrate leaching. Least significant differences, which are the standard errors of differences between means multiplied by the $t$ statistic for the degrees of freedom of the standard error, were used to compare means. We checked the assumptions of the statistical models using residual plots as described in McConway et al. (1999). Data on soil mineral $\mathrm{N}$ content were square root transformed and 
data on nitrate leaching were transformed by natural logarithm for analysis.

\section{Results and discussion}

In the present experiment, we examined the effects of the factors application technique of $\mathrm{N}$ fertilizer and rate of $\mathrm{N}$ application on nitrate losses in leaching water during winter under cut grassland on an organic-sandy soil. We further assessed herbage dry matter yield, $\mathrm{N}$ offtake with herbage, and residual soil mineral $\mathrm{N}$ content in autumn, and analyzed the effect of the experimental factors on these parameters. We finally used these parameters to derive $\mathrm{N}$ balances in individual treatment combinations of rate of $\mathrm{N}$ application and $\mathrm{N}$ application technique.

Results of the ANOVA revealed that the rate of $\mathrm{N}$ application had a highly significant $(p<0.001)$ effect on nitrate leaching during winter. In contrast, $\mathrm{N}$ fertilizer application technique did not have a significant effect on nitrate leaching. There was a significant interaction of the factors $\mathrm{N}$ application technique and rate of $\mathrm{N}$ application for nitrate leaching ( $p=$ 0.046).

In addition, the factor $\mathrm{N}$ application technique had a significant effect on herbage dry matter yield ( $p=0.004)$, and $\mathrm{N}$ offtake $(p<0.001)$ with higher values in chemical-synthetic $\mathrm{N}$ fertilization than in slurry treatments, whereas there were no significant differences in soil mineral $\mathrm{N}$ content in autumn among the treatments of $\mathrm{N}$ application technique. The rate of $\mathrm{N}$ application had a significant $(p<0.001)$ effect on herbage dry matter yield, $\mathrm{N}$ offtake, and soil mineral $\mathrm{N}$ content. There was a significant interaction of the factors $\mathrm{N}$ application technique and rate of $\mathrm{N}$ application for herbage dry matter yield and $\mathrm{N}$ offtake $(p<0.001)$.

Year had a significant $(p<0.001)$ effect on all of the measured parameters. The interaction of year and $\mathrm{N}$ application technique was significant for dry matter yield and $\mathrm{N}$ offtake $(p<0.02)$ while the interaction of year and rate of $\mathrm{N}$ application was significant for herbage dry matter yield, $\mathrm{N}$ offtake $(p<0.001)$, and nitrate leaching $(p=0.03)$.

On the basis of these results, we rejected the hypothesis that in productive grasslands on sandy soils, slurry application techniques that reduce gaseous losses (injection; application by sliding shoe) lead to larger losses of nitrate by leaching.

\subsection{Nitrate leaching}

Nitrate leaching during winter was generally very low and on average amounted to $5-16 \mathrm{~kg} \mathrm{~N}^{-1}$ for N0 to N320. Differences among $\mathrm{N}$ fertilizer application techniques, including chemical-synthetic fertilizer, were marginal (Table 2). In chemical-synthetic $\mathrm{N}$ fertilization and slurry injection, leaching tended to be lower in N160 than in N0; in slurry applied by sliding shoe, this effect was significant. Possibly, this can be explained by a denser and, hence, distinctly more productive sward on the N160 compared to the N0 plots. At inputs of more than $240 \mathrm{~kg} \mathrm{~N} \mathrm{ha}^{-1}$, nitrate leaching increased with increasing $\mathrm{N}$ input.

$\mathrm{NO}_{3}-\mathrm{N}$ concentrations in leaching water on a flowweighted annual basis only occasionally exceeded the target value of $11.3 \mathrm{mg} \mathrm{L}^{-1}$ set by the European Union: in years 2 and 3 for CAN320 (15.5 and $13.0 \mathrm{mg} \mathrm{N} \mathrm{L}^{-1}$, respectively) and for the N320 treatment in slurry applied by injection (12.8 and $11.9 \mathrm{mg} \mathrm{N} \mathrm{L}^{-1}$, respectively). In year 4, average $\mathrm{NO}_{3}-\mathrm{N}$ concentrations were $10.8,11.4$, and $10.1 \mathrm{mg} \mathrm{N} \mathrm{L}^{-1}$ for slurry applied broadcast, by sliding shoe and injection, respectively. Averaged over all years and $\mathrm{N}$ fertilizer application techniques, $\mathrm{NO}_{3}-\mathrm{N}$ concentrations amounted to $3.2,2.7,4.2$, and $7.7 \mathrm{mg} \mathrm{L}^{-1}$ for rates of $\mathrm{N}$ application of N0, N160, N240, and N320, respectively.

In mown grassland, leaching is known to amount to merely $2-10 \%$ of the $\mathrm{N}$ applied for fertilizer application rates of up to $250 \mathrm{~kg} \mathrm{~N} \mathrm{ha}^{-1}$ (Garwood and Ryden 1986) or $480 \mathrm{~kg} \mathrm{~N} \mathrm{ha}^{-1}$ (chemical-synthetic $\mathrm{N}$ fertilizer only, Benke 1992). In some years during our experiment leaching was less than 1.0-8.8 \% of the total $\mathrm{N}$ applied. Schröder et al. (2010) found in a 2-year experiment that at $\mathrm{N}$ application rates of up to $340 \mathrm{~kg} \mathrm{~N} \mathrm{ha}^{-1}$ $\mathrm{NO}_{3}-\mathrm{N}$ concentrations in groundwater did not exceed $11.3 \mathrm{mg} \mathrm{L}^{-1}$ on a wet sandy soil, whereas on a dry sandy soil all of the treatments did. Values obtained from sandy soils in our experiment range between those obtained from the wet and dry site of Schröder et al. (2010). Wachendorf et al. (2004) found in a cutting-only system that $\mathrm{NO}_{3}-\mathrm{N}$ concentrations were less than $11.3 \mathrm{mg} \mathrm{L}^{-1}$ up to a total input of $350 \mathrm{~kg} \mathrm{~N} \mathrm{ha}{ }^{-1}$ on a peaty podzol dominated by coarse soil texture in northern Germany. Leaching losses from slurry applications on mown grassland need not necessarily be higher than those from chemical-synthetic $\mathrm{N}$ fertilizer under similar conditions (Jarvis et al. 1987; Garwood and Ryden 1986). In the northeast USA, Stout et al. (2000) found leaching losses as low as 5.8 to $12.1 \mathrm{~kg} \mathrm{~N}^{-1}$ under orchard grass with slurry application rates of $0,168,336$, and $672 \mathrm{~kg} \mathrm{~N} \mathrm{ha}{ }^{-1}$. In this experiment, the total $\mathrm{N}$ and $\mathrm{C}$ in the soil (i.e., organic matter) had a greater effect on nitrate leaching than the slurry application did. Similarly, we found an increase in soil mineral $\mathrm{N}$ content with increasing total $\mathrm{C}$ and $\mathrm{N}$ in the topsoil in $\mathrm{N} 0$ plots and when $\mathrm{N}$ was applied. However, the effect of $\mathrm{N}$ input from fertilizers was greater than the effect of soil C and N (Kayser et al. 2004).

\subsection{Herbage dry matter yield and $\mathrm{N}$ offtake}

In a mown grassland system, nutrient removal with plant offtake plays a major role in nutrient cycling and is influenced by the rate of fertilizer application and weather conditions during spring and summer (Whitehead 1995). The differences 
Table 2 Dry matter (DM) yield, $\mathrm{N}$ offtake, soil mineral $\mathrm{N}$ content (SMN), and $\mathrm{N}$ leaching $\left(\mathrm{NO}_{3}-\mathrm{N}\right)$ during winter (October to April) for the four $\mathrm{N}$ fertilizer application techniques (CAN, calcium ammonium nitrate; CSb, cattle slurry, broadcast application; CSs, cattle slurry, sliding shoe application; CSi, cattle slurry, open slot shallow injection) and four levels of amount of $\mathrm{N}$ input averaged over the four experimental years; means and least significant differences (1.s.d., $p<0.05$ ); 1.s.d. values for $\mathrm{SMN}$ and $\mathrm{N}$ leaching are based on square root and log transformed data, respectively; values in brackets given for comparison within the same level of $\mathrm{N}$ fertilizer application technique

\begin{tabular}{|c|c|c|c|c|c|c|c|}
\hline $\begin{array}{l}\mathrm{N} \text { fertilizer application } \\
\text { technique }\end{array}$ & $\begin{array}{l}\text { Amount of } \mathrm{N} \text { input } \\
{\left[\mathrm{kg} \mathrm{ha}^{-1}\right]}\end{array}$ & $\begin{array}{l}\text { DM yield } \\
{\left[\mathrm{t} \mathrm{ha}^{-1}\right]}\end{array}$ & $\begin{array}{l}\mathrm{N} \text { offtake } \\
{\left[\mathrm{kg} \mathrm{ha}^{-1}\right]}\end{array}$ & $\begin{array}{l}\text { SMN } \\
{\left[\mathrm{kg} \mathrm{ha}^{-1}\right]}\end{array}$ & $\begin{array}{l}\text { SMN (sqrt transf.) } \\
{\left[\mathrm{kg} \mathrm{ha}^{-1}\right]}\end{array}$ & $\begin{array}{l}\text { N leaching } \\
{\left[\mathrm{kg} \mathrm{ha}^{-1}\right]}\end{array}$ & $\begin{array}{l}\text { N leaching (log transf.) } \\
{\left[\mathrm{kg} \mathrm{ha}^{-1}\right]}\end{array}$ \\
\hline \multirow[t]{4}{*}{ CAN } & 0 & 5.64 & 138 & 34.7 & 5.75 & 5.98 & 1.28 \\
\hline & 160 & 9.55 & 229 & 28.4 & 5.19 & 5.51 & 0.96 \\
\hline & 240 & 10.88 & 282 & 25.1 & 4.92 & 5.92 & 1.28 \\
\hline & 320 & 11.77 & 324 & 44.4 & 6.50 & 15.56 & 2.55 \\
\hline \multirow[t]{4}{*}{$\mathrm{CSb}$} & 0 & 5.14 & 114 & 28.2 & 5.14 & 5.06 & 0.97 \\
\hline & 160 & 7.74 & 169 & 29.2 & 5.19 & 5.27 & 1.03 \\
\hline & 240 & 8.51 & 200 & 33.9 & 5.70 & 11.09 & 1.97 \\
\hline & 320 & 8.61 & 204 & 39.3 & 6.04 & 9.77 & 1.80 \\
\hline \multirow[t]{4}{*}{$\mathrm{CSs}$} & 0 & 4.94 & 114 & 30.1 & 5.35 & 7.81 & 1.60 \\
\hline & 160 & 7.80 & 175 & 32.5 & 5.59 & 4.97 & 0.96 \\
\hline & 240 & 8.14 & 184 & 32.7 & 5.52 & 6.58 & 1.14 \\
\hline & 320 & 9.28 & 221 & 39.6 & 6.03 & 13.92 & 2.22 \\
\hline \multirow[t]{4}{*}{$\mathrm{CSi}$} & 0 & 4.51 & 102 & 25.3 & 4.94 & 5.47 & 0.90 \\
\hline & 160 & 8.47 & 203 & 27.8 & 5.16 & 5.01 & 1.29 \\
\hline & 240 & 8.78 & 220 & 27.0 & 5.00 & 7.08 & 1.62 \\
\hline & 320 & 9.56 & 253 & 37.9 & 6.09 & 16.23 & 2.46 \\
\hline CAN & & 9.46 & 243 & 33.2 & 5.59 & 8.24 & 1.52 \\
\hline $\mathrm{CSb}$ & & 7.50 & 172 & 32.6 & 5.52 & 7.80 & 1.44 \\
\hline $\mathrm{CSs}$ & & 7.54 & 174 & 33.7 & 5.62 & 8.32 & 1.48 \\
\hline \multirow[t]{5}{*}{$\mathrm{CSi}$} & & 7.83 & 194 & 29.5 & 5.30 & 8.45 & 1.57 \\
\hline & 0 & 5.06 & 117 & 29.6 & 5.29 & 6.08 & 1.19 \\
\hline & 160 & 8.39 & 194 & 29.5 & 5.28 & 5.19 & 1.06 \\
\hline & 240 & 9.08 & 221 & 29.7 & 5.29 & 7.67 & 1.50 \\
\hline & 320 & 9.81 & 250 & 40.3 & 6.17 & 13.87 & 2.26 \\
\hline 1.s.d., $\mathrm{N}$ appl. technique, $T$ & & 0.964 & 26.1 & & ns & & ns \\
\hline 1.s.d., $\mathrm{N}$ appl. rate, $A$ & & 0.351 & 12.5 & & 0.364 & & 0.336 \\
\hline 1.s.d., $T \times A$ & & $1.091(0.70)$ & $32.3(25.0)$ & & ns & & $0.732(0.671)$ \\
\hline
\end{tabular}

in herbage dry matter yield, $\mathrm{N}$ offtake, and nutrient losses among years can therefore be substantial (Ledgard 2001; Benke 1992). Our data highlighted differences in dry matter yield among years; especially year 3 showed distinctively smaller yields which had been the result of a cool summer with high rainfall in August and October (Table 1).

The average dry matter yields over the years for N0 plots were affected by the relatively large values in the fourth year (values not shown) that were due to an invasion of white clover in these plots. The levelling and only marginally increasing or even decreasing yields for the slurry treatments at $\mathrm{N}$ input $\geq 240 \mathrm{~kg} \mathrm{~N} \mathrm{ha}^{-1}$ (Tab. 2) may, apart from the generally limited water resources in this course-textured soil, be explained by the experimental settings. Application of fertilizers was made in doses of $80 \mathrm{~kg} \mathrm{~N} \mathrm{ha}^{-1}$; for the $\mathrm{N} 320$ treatments, this meant four times of wheel traffic with possible damage to the sward (especially in slurry injection) and increased gaseous losses during summer (especially in broadcast application of slurry). According to other studies, a close to linear response of herbage yield of 20-30 kg dry matter per $\mathrm{kg} \mathrm{N}$ up to fertilizer levels of $250-400 \mathrm{~kg} \mathrm{~N}^{-1}$ can be expected (Whitehead 1995; and references there).

Although the proportion of $\mathrm{NH}_{4}-\mathrm{N}$ in total $\mathrm{N}$ supplied with cattle slurry was only about $60 \%$, dry matter yield and $\mathrm{N}$ offtake in cattle slurry treatments were 80 and $73 \%$, respectively, those of calcium ammonium nitrate treatments for applications of $80-320 \mathrm{~kg} \mathrm{~N}^{-1}$. This implies that part of the organic $\mathrm{N}$ in the slurry had been mineralized from the first year onwards. Schröder et al. (2005) investigated the effects of long-term $\mathrm{N}$ supply from cattle slurry, and model calculations indicated that the $\mathrm{N}$ fertilizer replacement value of cattle slurry increased from approximately $55-60 \%$ in the first application 
to approximately $80 \%$ when continuously applied over $6-$ 8 years. It has further been suggested that adding slurry to the soil enhances mineralization as a priming effect (Kuzyakov et al. 2000). This may be applicable to our experimental field that had a history of manure applications over at least the previous two decades.

The patterns of $\mathrm{N}$ offtake were similar to those described for dry matter yields but more pronounced (Table 2). In N0, the average $\mathrm{N}$ offtake amounted to $117 \mathrm{~kg} \mathrm{~N} \mathrm{ha}^{-1}$ (86 $\mathrm{kg} \mathrm{N} \mathrm{ha}^{-1}$ for years $1-3$ ). Nitrogen was provided by mineralization and atmospheric deposition and, in year 4 , additionally by a contribution of white clover to the control plots. The difference in $\mathrm{N}$ offtake for the control plots in year 4 to the average of the control plots in the three previous years was $119 \mathrm{~kg} \mathrm{~N} \mathrm{ha}^{-1}$, but only $40 \mathrm{~kg} \mathrm{~N} \mathrm{ha}^{-1}$ for the average of all fertilized treatments. An application of $320 \mathrm{~kg} \mathrm{~N}$ ha $^{-1}$ resulted in an average $\mathrm{N}$ offtake of $324 \mathrm{~kg} \mathrm{~N} \mathrm{ha}^{-1}$ in the plots receiving chemical-synthetic fertilizer, but an N offtake of merely 204 (broadcast application) to 253 (injection) $\mathrm{kg} \mathrm{N} \mathrm{ha}^{-1}$ in the slurry treatments, which corresponds to 64 and $79 \%$, respectively, of total $\mathrm{N}$ applied.

\subsection{Apparent $\mathrm{N}$ recovery}

Apparent $\mathrm{N}$ recovery was greater for chemical-synthetic $\mathrm{N}$ fertilizer than for slurries and decreased with increasing $\mathrm{N}$ application rate (Table 3), but did not exceed $75 \%$ for mineral fertilizer (CAN240) or $67 \%$ for injected slurry (N160). Recovery of $\mathrm{N}$ was better for slurry injection than for broad spreading or sliding shoe application and, consequently, $\mathrm{N}$ fertilizer replacement value amounted to $79 \%$ for slurry injection compared to less than $56 \%$ for the other slurry application techniques. For soils similar to those in our experiment, Groot et al. (2007) and Schröder et al. (2010) found higher values of apparent $\mathrm{N}$ recovery for shallow injection compared to broadcast; Schröder et al. (2010) reported an average $\mathrm{N}$ fertilizer replacement value of $60 \%$ for shallow injection.

Table 3 Apparent $\mathrm{N}$ recovery (ANR) and $\mathrm{N}$ fertilizer replacement value (NFRV) for four $\mathrm{N}$ fertilizer application techniques at three levels of amount of $\mathrm{N}$ input $\left(160,240\right.$, and $320 \mathrm{~kg} \mathrm{~N} \mathrm{ha}^{-1}$ year $^{-1}$ for $\mathrm{N} 160$, $\mathrm{N} 240$, and N320, respectively; controls at $0 \mathrm{~kg} \mathrm{~N} \mathrm{ha}^{-1}$ year $^{-1}$, N0). $\mathrm{CAN}$, calcium ammonium nitrate; $\mathrm{CSb}$, cattle slurry, broadcast
When only the first cut was considered, apparent $\mathrm{N}$ recovery for chemical-synthetic fertilizer was $73 \%$ on average, but only $28-47 \%$ for the slurry treatments with the highest values for slurry injection. In slurry application, apparent $\mathrm{N}$ recovery in the first cut increased with increasing $\mathrm{N}$ application rate from $31 \%$ in the N160 treatment to $43 \%$ in N320. As all treatments had only received $80 \mathrm{~kg} \mathrm{~N} \mathrm{ha}^{-1}$ before the first cut, this indicates a carry-over effect of autumn application of $\mathrm{N}$ to spring: some $\mathrm{N}$ had obviously been preserved over winter and added to the $\mathrm{N}$ supply when growth started the following year. For broadcast slurry application, Smith et al. (2002) observed a better $\mathrm{N}$ recovery in spring from applications made in September and October of the previous year than from earlier applications in June. On top of that, damage to the sward in spring which is likely to have occurred with injection may have further stimulated mineralization processes and added to $\mathrm{N}$ supply.

When chemical-synthetic $\mathrm{N}$ fertilizers and slurries are compared with regard to their effects on plant production and nitrate leaching, gaseous losses should be considered. Generally, the efficiency of $\mathrm{N}$ from slurry is likely to be reduced by $\mathrm{NH}_{3}$ and denitrification, and $\mathrm{N}_{2} \mathrm{O}$ losses following application and transformation processes of organic $\mathrm{N}$ in the soil. Volatile losses are greatly influenced by the amount of total ammoniacal $\mathrm{N}$ in the slurry, weather conditions, and plant uptake. Flessa et al. (2012) conclude that it is difficult to reduce $\mathrm{NH}_{3}$ and $\mathrm{N}_{2} \mathrm{O}$ losses at the same time and state the need for a compromise. $\mathrm{NH}_{3}$ losses increase with temperature and solar radiation whereas $\mathrm{N}_{2} \mathrm{O}$ losses are promoted by finer soil texture, soil compaction, and higher water content. Flessa et al. (2012) report data from Döhler et al. (2002) who found that $\mathrm{NH}_{3}$ emissions from grassland were 60,40 , and $10 \%$ lower with shallow injection, trailing shoe, and trailing hose, respectively, than in broadcast application. Misselbrook et al. (2002) even recorded reductions of 73,57 , and $26 \%$, respectively. In a comprehensive review on the subject, Webb et al. (2010) report average reductions in $\mathrm{NH}_{3}$ emissions compared to broadcast application of 80,64 , and $35 \%$ for injection, trailing shoe, and trailing hose, respectively, but also found

application; CSs, cattle slurry, sliding shoe application; CSi, cattle slurry, open slot shallow injection. For slurries, total $\mathrm{N}$ content was considered. Year 4 was excluded as $\mathrm{N}$ offtake for $\mathrm{N} 0$ was exceptionally high due to an invasion of white clover. Treatments CAN and CSs were extended to 6 years (omitting year 4 again for 5 -year mean of ANR)

\begin{tabular}{lllllll}
\hline N application technique & \multicolumn{2}{l}{ ANR [\%] } & & & \\
\cline { 2 - 6 } & N160 & N240 & N320 & Mean (3 years) & Mean (5 years) & $(3$ years) \\
\hline CAN & 74 & 75 & 70 & 73 & 71 & 100 \\
$\mathrm{CSb}$ & 45 & 42 & 34 & 40 & 39 & 56 \\
$\mathrm{CSs}$ & 45 & 38 & 40 & 41 & 58 \\
$\mathrm{CSi}$ & 67 & 56 & 52 & 58 & 79 \\
\hline
\end{tabular}


large variations in percentage reduction for each of the techniques. It is likely that the positive effects of injection (reduced gaseous losses) have been counteracted by the negative effects of multiple injections per year-in our experimental design the higher the $\mathrm{N}$ supply the more often slurry was injected. This may have caused damage to the sward which may have resulted in the nonlinear response to $\mathrm{N}$ supply of dry matter yields and $\mathrm{N}$ offtake.

3.4 Relationship between soil mineral $\mathrm{N}$ content, $\mathrm{N}$ surplus, and nitrate leaching

Soil mineral N content in autumn was a reasonably good predictor for nitrate leaching $\left(R_{\text {adj }}^{2}=0.65\right)$ (Fig. 2a). Schröder et al. (2010) found only a weak relationship between residual soil mineral $\mathrm{N}$ content and nitrate concentrations in upper groundwater that was not consistent across sites and years $\left(R_{\text {adj }}^{2}=0.19\right)$. They found that similar soil mineral $\mathrm{N}$ content values were related to much higher $\mathrm{NO}_{3}-\mathrm{N}$ concentrations on the dry site than on the wet site. The relationship between soil mineral $\mathrm{N}$ content and nitrate leaching for sandy soils reported by Wachendorf et al. (2004) was even stronger at $R_{\text {adj }}^{2}=0.74$. Variability may partly be explained by weather effects, late mineralization during autumn and winter, and by the nature of soil mineral $\mathrm{N}$ content being sampled at one point in time. The relationship between $\mathrm{N}$ surplus (including deposition) and nitrate leaching (Fig. 2b) was not that strong and merely amounted to $R_{\text {adj }}^{2}=0.31$. Predictions of nitrate leaching based on effective surpluses $\left(R_{\text {adj }}^{2}=0.41\right)$ were slightly better than those based on simple surpluses (Fig. 2c). The effective surplus takes account of the fact that only certain portions of slurry total $\mathrm{N}$ are directly plant available (slurry total $\mathrm{N} \times \mathrm{N}$ fertilizer replacement value); Schröder et al. 2010 found the effective surplus to be a good indicator for nitrate leaching $\left(R_{\text {adj }}^{2}=0.86\right)$. The rather weak relationships of $R^{2}$ adj $=0.31$ and
$R_{\text {adj }}^{2}=0.41$ in our experiment reflect that similar surpluses might result in a wide range of values of nitrate leaching. Nitrate leaching depended to a great extent on the amount of rainfall during winter. Schröder et al. (2010) based their findings on 2 years and two sites with relatively small differences in rainfall, while in our 4-year experiment the range in precipitation was much wider, thus weakening the relationship between $\mathrm{N}$ surplus and nitrate leaching.

Wachendorf et al. (2004) found that nitrate leaching accounted for only $33-40 \%$ of calculated excess in the system which points to the significance of other pathways of $\mathrm{N}$ loss in cut grassland. In our investigation the proportion of nitrate leaching of positive $\mathrm{N}$ surpluses increased in the order broadcast, sliding shoe, injection, and chemical-synthetic $\mathrm{N}$ application and decreased with $\mathrm{N}$ application rate. Leaching losses amounted to only 10, 14, and $24 \%$ of positive surpluses ( $\mathrm{N}$ application - N offtake) at N320 in slurry treatments for broadcast application, sliding shoe, and injection of slurry, respectively.

In our experiments, some of the calculated surplus values, in particular effective surpluses, were negative (Table 4) resulting in relatively small nitrate leaching losses. This may indicate that utilization of slurry $\mathrm{N}$ was better than expected from our calculations or that there were additional sources of $\mathrm{N}$ for plant uptake. Deposition of atmospheric $\mathrm{N}$ in northwest Germany amounts to approximately $30 \mathrm{~kg} \mathrm{~N} \mathrm{ha}^{-1}$ (Table 4). Besides, the soil at the experimental site has a certain mineralization potential as the sandy soil had been mixed with overlying peat in the 1970s. The $\mathrm{N}$ offtake of on average $86 \mathrm{~kg} \mathrm{~N} \mathrm{ha}^{-1}$ at $\mathrm{N} 0$ for the first three experimental years confirms this. On an adjacent maize field with total carbon being more than $4.0 \%$ compared to an average $2.7 \%$ total carbon on the grassland site, regular tillage and probably a slow release of $\mathrm{C}$ and $\mathrm{N}$ from old organic residues led to consistently good maize yields even with no $\mathrm{N}$ input (Kayser et al. 2011).

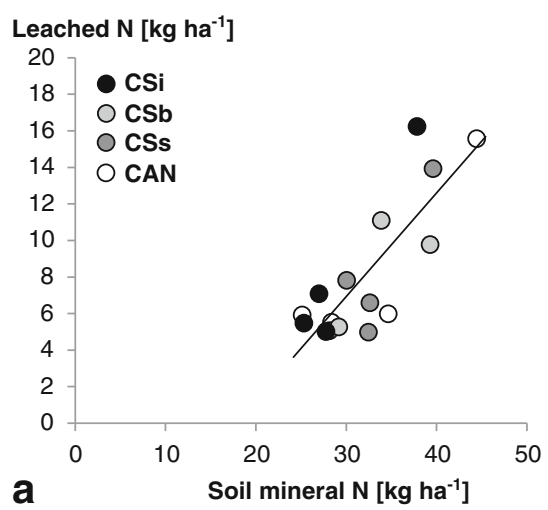

Fig. 2 The relationship between a soil mineral $\mathrm{N}$ content in autumn $\left(\mathrm{kg} \mathrm{ha}^{-1}\right)$ and $\mathrm{N}\left(\mathrm{NO}_{3}-\mathrm{N}\right)$ leached during winter $\left(\mathrm{kg} \mathrm{ha}^{-1}\right)$, means of 4 years, $y=0.566 x-10.06\left(R_{\text {adj }}^{2}=0.65, p<0.001, \mathrm{SE}=2.31\right)$; b N surplus $\left(\mathrm{kg} \mathrm{ha}^{-1}\right)\left(\mathrm{N}\right.$ applied + deposition $\left(30 \mathrm{~kg} \mathrm{~N} \mathrm{ha}^{-1}\right)-\mathrm{N}$ offtake with biomass) and $\mathrm{N}$ leached during winter $\left(\mathrm{kg} \mathrm{ha}^{-1}\right)$, means of 4 years, $y=$ $0.0295 x+7.78\left(R_{\text {adj }}^{2}=0.31, p=0.015, \mathrm{SE}=3.26\right)$; $\mathbf{c}$ effective $\mathrm{N}$ surplus
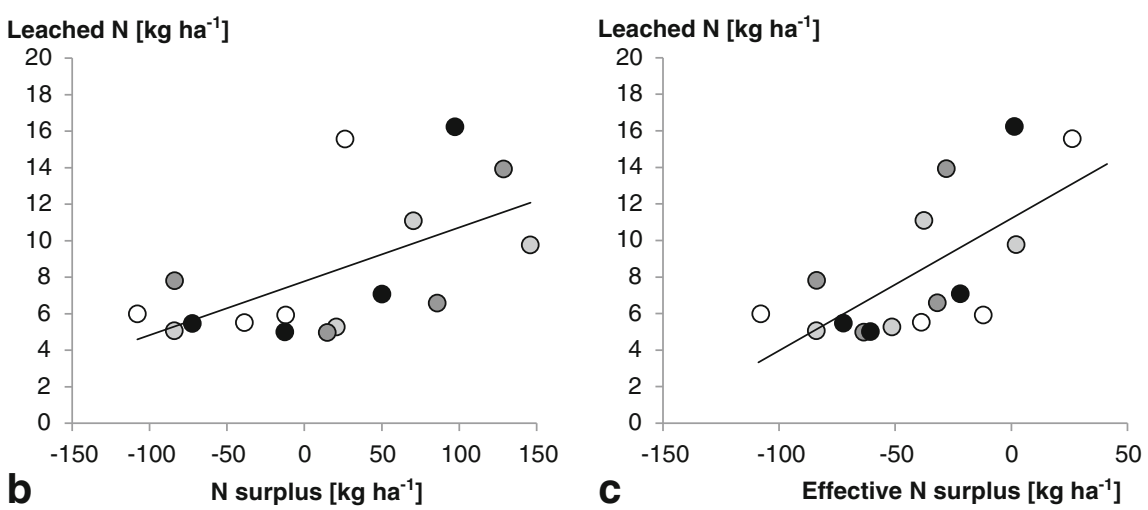

$\left(\mathrm{kg} \mathrm{ha}^{-1}\right)$ (Eqs. 2a and 2b) and $\mathrm{N}$ leached during winter $\left(\mathrm{kg} \mathrm{ha}^{-1}\right)$, means of 4 years, $y=0.0723 x+13.37\left(R_{\text {adj }}^{2}=0.41, p=0.004, \mathrm{SE}=3.01\right)$, for different fertilizer application techniques. $C A N$, calcium ammonium nitrate; $C S b$, cattle slurry, broadcast application; $C S s$, cattle slurry, sliding shoe application; $C S i$, cattle slurry, open slot shallow injection 
Table 4 Balances showing values of unaccounted $\mathrm{N}$ loss. TAN, total ammoniacal nitrogen input: TAN $=100 \%$ total $\mathrm{N}(\mathrm{TN})$ in CAN or $60 \%$ TN in slurry. $\mathrm{NH}_{3}$ volatilization, gaseous $\mathrm{NH}_{3}$ loss from slurry: estimates for $\mathrm{N} 160, \mathrm{~N} 240, \mathrm{~N} 320: \mathrm{CSb}=70,75$, and $80 \%$ of TAN, CSs $=25,27$, $30 \%$ of TAN, CSi $=10,15,17 \%$ of TAN, respectively (estimates based on own experiments (Pape 1995, unpublished report) and values from literature (Misselbrook et al. 2002; Flessa et al. 2012, and references there)); total atmospheric $\mathrm{N}$ deposition: $30 \mathrm{~kg} \mathrm{~N}^{-1}$ (Lower Saxony Ministry 2013); $\mathrm{N}$ unaccounted for (1): $\mathrm{TN}+$ deposition $-\mathrm{N}$ offtake $+\mathrm{N}$ leaching; $\mathrm{N}$ unaccounted for (2): $\mathrm{TN}-\mathrm{NH}_{3}$ volatilization + deposition $-\mathrm{N}$ offtake $+\mathrm{N}$ leaching

\begin{tabular}{|c|c|c|c|c|c|c|c|}
\hline Fertilizer $\mathrm{N}$ form & $\begin{array}{l}\text { Total N input } \\
{\left[\mathrm{kg} \mathrm{ha}^{-1}\right]}\end{array}$ & $\begin{array}{l}\text { TAN input } \\
{\left[\mathrm{kg} \mathrm{ha}^{-1}\right]}\end{array}$ & $\begin{array}{l}\mathrm{NH}_{3} \text { volatilization } \\
{\left[\mathrm{kg} \mathrm{ha}^{-1}\right]}\end{array}$ & $\begin{array}{l}\text { N leaching } \\
{\left[\mathrm{kg} \mathrm{ha}^{-1}\right]}\end{array}$ & $\begin{array}{l}\mathrm{N} \text { offtake } \\
{\left[\mathrm{kg} \mathrm{ha}^{-1}\right]}\end{array}$ & $\begin{array}{l}\mathrm{N} \text { unaccounted for (1) } \\
{\left[\mathrm{kg} \mathrm{ha}^{-1}\right]}\end{array}$ & $\begin{array}{l}\mathrm{N} \text { unaccounted for }(2) \\
{\left[\mathrm{kg} \mathrm{ha}^{-1}\right]}\end{array}$ \\
\hline \multirow[t]{4}{*}{ CAN } & 0 & 0 & & 6 & 138 & -114 & -114 \\
\hline & 160 & 160 & & 5 & 229 & -44 & -44 \\
\hline & 240 & 240 & & 6 & 282 & -18 & -18 \\
\hline & 320 & 320 & & 16 & 324 & 10 & 10 \\
\hline \multirow[t]{4}{*}{$\mathrm{CSb}$} & 0 & 0 & 0 & 5 & 114 & -89 & -89 \\
\hline & 160 & 96 & 38 & 5 & 169 & 16 & -22 \\
\hline & 240 & 144 & 72 & 11 & 200 & 59 & -13 \\
\hline & 320 & 192 & 115 & 10 & 204 & 136 & 21 \\
\hline \multirow[t]{4}{*}{ CSs } & 0 & 0 & 0 & 5 & 114 & -89 & -89 \\
\hline & 160 & 96 & 19 & 5 & 175 & 10 & -9 \\
\hline & 240 & 144 & 36 & 7 & 184 & 79 & 43 \\
\hline & 320 & 192 & 58 & 14 & 221 & 115 & 57 \\
\hline \multirow[t]{4}{*}{$\mathrm{CSi}$} & 0 & 0 & 0 & 5 & 102 & -77 & -77 \\
\hline & 160 & 96 & 14 & 5 & 203 & -18 & -32 \\
\hline & 240 & 144 & 25 & 7 & 220 & 43 & 18 \\
\hline & 320 & 192 & 38 & 16 & 253 & 81 & 43 \\
\hline
\end{tabular}

$C A N$, calcium ammonium nitrate; $C S b$, cattle slurry, broadcast application; $C S s$, cattle slurry, sliding shoe application; CSi, cattle slurry, open slot shallow injection

\subsection{Limitations of large slurry $\mathrm{N}$ inputs on cut grassland}

Productive grassland encompasses large offtakes of $\mathrm{N}$, which in our experiment resulted in $\mathrm{N}$ surpluses of less than $50 \mathrm{~kg} \mathrm{~N} h a^{-1}$ when estimates of gaseous losses were considered. Estimated gaseous losses, $\mathrm{NH}_{3}$ in particular, were 1, 9, 5, and 3.5 times larger than respective leaching losses for calcium ammonium nitrate and cattle slurry applied broadcast, by sliding shoe, and injection (average of N160-N320) (Table 4). On sandy soil, $\mathrm{NH}_{3}$ is likely to account for more than $95 \%$ of gaseous losses. Losses from $\mathrm{N}_{2} \mathrm{O}$ and denitrification are less important but are likely to increase if slurry is injected (Flessa et al. 2012; Webb et al. 2010; Misselbrook et al. 2002). Including estimates for $\mathrm{N}_{2} \mathrm{O}$ and denitrification of 2, 3, and $5 \%$ for cattle slurry applied broadcast, by sliding shoe, and injection would amount to total gaseous $\mathrm{N}$ losses of 50, 25, and $17.5 \%$ of total ammoniacal $\mathrm{N}$, respectively. With regular injection, there is an increasing risk of damage to the sward and soil compaction under unfavorable site conditions (Webb et al. 2010). Even after including estimates for volatile losses, values of $\mathrm{N}$ unaccounted for appear to be rather high, particularly in those treatments where no $\mathrm{N}$ fertilization was applied or where $320 \mathrm{~kg} \mathrm{~N} \mathrm{ha}^{-1}$ were applied (Table 4). Apart from uncertainty in estimating gaseous losses, higher values for $\mathrm{N}$ unaccounted for point at processes in $\mathrm{N}$ cycling that are difficult to include in balances (Jarvis 2000). Nitrogen unaccounted for in plant uptake and leaching is often regarded as being immobilized in the form of organic matter in the soil, stored in roots and stubble or lost via ammonia volatilization or denitrification. The grassland sward at the experimental site had been sown only 3 years before the experiment started and it is likely that some $\mathrm{N}$ was still being immobilized during the ongoing development of the sward (Whitehead 1995). With increasing inputs of slurry, $\mathrm{N}$ unaccounted for increased and was 2 to 4.5 times that of $\mathrm{N}$ leaching, even when $\mathrm{NH}_{3}$ losses had been considered.

In Kayser et al. (2007) it was shown that a larger input of $\mathrm{N}$ in the form of slurry resulted in increased inputs of $\mathrm{P}$ and $\mathrm{K}$. We found $\mathrm{P}$ balances of $+25 \mathrm{~kg} \mathrm{P}^{-1}$ for N240 slurry treatments ( $\mathrm{P}$ input of $57 \mathrm{~kg} \mathrm{ha}^{-1}$ ) and $+42 \mathrm{~kg} \mathrm{P} \mathrm{ha}^{-1}$ for N320 slurry treatment ( $\mathrm{P}$ input of $\left.76 \mathrm{~kg} \mathrm{ha}^{-1}\right)$, but only $+6 \mathrm{~kg}$ $\mathrm{P} \mathrm{ha}^{-1}$ for N320 as chemical synthetic fertilizer (input of $48 \mathrm{~kg}$ $\mathrm{P} \mathrm{ha}^{-1}$ in mineral form). There was no increase in exchangeable $\mathrm{P}$ (double lactate method) for slurry application rates of up to $240 \mathrm{~kg} \mathrm{~N} \mathrm{ha}^{-1}$. Balances of $\mathrm{K}$ for slurry treatments were $-19,+59$, and $+134 \mathrm{~kg} \mathrm{~K} \mathrm{ha}^{-1}$ for N160, N240, and N320, respectively. Exchangeable $\mathrm{K}$ in topsoil was almost twice as much in N320 as in N160, and K leaching losses also increased. In agricultural practice in order to prevent large $\mathrm{P}$ and $\mathrm{K}$ surpluses, slurry is usually combined with the application of 
chemical-synthetic $\mathrm{N}$ fertilizer. A combination of slurry and chemical-synthetic $\mathrm{N}$ fertilizer would probably have improved apparent $\mathrm{N}$ recovery and $\mathrm{N}$ fertilizer replacement value without having a major impact on $\mathrm{N}$ losses from nitrate leaching.

\section{Conclusion}

We have shown that on productive cut grassland on an organic-sandy soil differences in nitrate leaching, as well as in dry matter yield and soil mineral $\mathrm{N}$ content, were marginal among the different slurry application techniques. Nitrate leaching during winter was generally very low and on average amounted to $5-16 \mathrm{~kg} \mathrm{~N} \mathrm{ha}^{-1}$ and concentrations of $7.7 \mathrm{mg}$ $\mathrm{NO}_{3}-\mathrm{N} \mathrm{L}^{-1}$ for $\mathrm{N}$ input up to $320 \mathrm{~kg} \mathrm{~N} \mathrm{ha}^{-1}$. Our results indicate that the intensive management encompassing high amounts of $\mathrm{N}$ fertilizer input and high $\mathrm{N}$ offtake resulted in minor $\mathrm{N}$ surpluses; calculated values of effective surpluses often were negative. Even after including estimates for volatile losses, values of $\mathrm{N}$ unaccounted for appeared to be rather high and for $\mathrm{N}$ application rates of more than $240 \mathrm{~kg} \mathrm{ha}^{-1}$ in slurry were 2 to 4.5 times that of $\mathrm{NO}_{3}-\mathrm{N}$ leaching losses. However, $\mathrm{P}$ and $\mathrm{K}$ balances of $+25 \mathrm{~kg} \mathrm{P} \mathrm{ha}^{-1}$ and + $59 \mathrm{~kg} \mathrm{~K} \mathrm{ha}{ }^{-1}$ were calculated for slurry inputs of $240 \mathrm{~kg} \mathrm{~N} \mathrm{ha}^{-1}$. In agricultural practice in order to prevent large $\mathrm{P}$ and $\mathrm{K}$ surpluses, slurry is usually combined with the application of chemical-synthetic $\mathrm{N}$ fertilizer. A combination of slurry and chemical-synthetic $\mathrm{N}$ fertilizer as common practice would probably have improved apparent $\mathrm{N}$ recovery and $\mathrm{N}$ fertilizer replacement value without having a major impact on $\mathrm{N}$ losses from nitrate leaching. Furthermore, when slurry is being applied regularly over a longer period of time, slurry decomposition rates should be considered which may entail higher $\mathrm{N}$ fertilizer replacement values.

Acknowledgments This work was supported by the Federal State of Lower-Saxony, Germany. We would like to thank Hubert Koopmann for allowing us to set up the experimental field on his farm, and Barbara Thomann and Annette Kayser for technical assistance.

\section{References}

Benke M (1992) Untersuchungen zur Nitratauswaschung unter Grünland mittels der Saugkerzen-Methode in Abhängigkeit von der Nutzungsart (Schnitt/Weide), der Nutzungshäufigkeit, der Bestandeszusammensetzung (mit/ohne Weißklee) und der Stickstoffdüngung. $\mathrm{PhD}$ thesis, Christian-Albrechts-Universität zu Kiel

Bussink DW, Oenema O (1998) Ammonia volatilization from dairy farming systems in temperate areas: a review. Nutr Cycl Agroecosyst 51:19-33. doi:10.1023/A:1009747109538

Döhler H, Eurich-Menden B, Dämmgen U, Osterburg B, Lüttich M, Bergschmidt A, Berg W, Brunsch R (2002) BMELV/UBAAmmoniak-Emissionsinventar der deutschen Landwirtschaft und
Minderungszenarien bis zum Jahr 2010. Forschungsbericht 29942 256/02. Texte 05/02. Umweltbundesamt Berlin

DVWK (1996) Ermittlung der Verdunstung von Land- und Wasserflächen. (Measuring transpiration from Land and Water Surfaces). DVWK-Merkblätter 238, Bonn

Flessa H, Müller D, Plassmann K, Osterburg B, Techen A-K, Nitsch H, Nieberg H, Sanders J, Meyer zu Hartlage O, Breckmann E, Anspach V (2012) Studie zur Vorbereitung einer effizienten und gut abgestimmten Klimaschutzpolitik für den Agrarsektor. vTI Agriculture and Forestry Research, Special Issue 361

Garwood EA, Ryden JC (1986) Nitrate loss through leaching and surface runoff from grassland: effects of water supply, soil type and management. In: Van der Meer HG, Ryden JC, Ennik GC (eds) Nitrogen fluxes in intensive grassland systems. Martinus Nijhoff, Dordrecht, pp 99-113

Groot JCJ, Van der Ploeg JD, Verhoeven FPM, Lantinga EA (2007) Interpretation of results from on-farm experiments: manurenitrogen recovery on grassland as affected by manure quality and application technique. 1. An agronomic analysis. Neth J Agric Sci 54:235-254. doi:10.1016/S1573-5214(07)80017-0

Gutser R, Ebertseder T, Weber A, Schraml M, Schmidhalter U (2005) Short-term and residual availability of nitrogen after long-term application of organic fertilizers on arable land. J Plant Nutr Soil Sci 168:439-446. doi:10.1002/jpln.200520510

Jarvis SC (2000) Progress in studies of nitrate leaching from grassland soils. Soil Use Manag 16:152-156. doi:10.1111/j.1475-2743.2000. tb00219.x

Jarvis SC, Sherwood M, Steenvorden JHAM (1987) Nitrogen losses from animal manures: from grazed pastures and from applied slurry. In: Van der Meer HG, Unwin RJ, Van Dijk TA, Ennik GC (eds) Animal manure on grassland and fodder crops. Martinus Nijhoff, Dordrecht, pp 1195-1221

Javis SC, Pain BF (eds) (1997) Gaseous emissions from grasslands. CAB International, Wallingford

Kayser M, Müller J, Isselstein J (2004) Within-field variation in the amount of soil mineral nitrogen in autumn as related to organic carbon and total nitrogen content in the topsoil. Book of Abstracts, Eurosoil, Freiburg, 2004, p.419

Kayser M, Müller J, Isselstein J (2007) Potassium leaching from cut grassland and from urine patches. Soil Use Manag 23: 384-392

Kayser M, Benke M, Isselstein J (2011) Little fertilizer response but high $\mathrm{N}$ loss risk of maize growing on a productive organic-sandy soil. Agron Sustain Dev 31:709-718. doi:10.1007/s13593-011-0046-9

Kuzyakov Y, Fiedel JK, Stahr K (2000) Review of mechanisms and quantification of priming effects. Soil Biol Biochem 32:14851498. doi:10.1016/s0038-0717(00)00084-5

Ledgard SF (2001) Nitrogen cycling in low input legume-based agriculture, with emphasis on legume/grass pastures. Plant Soil 228:43-59. doi:10.1023/A:1004810620983

Lower Saxony Ministry Report (2013) http://www.umwelt. niedersachsen.de/umweltbericht/herausforderungen/eutrophierung/ naehrstoffeintrag_durch_deposition/quellen_und_eintraege/ quellen-und-eintraege-88992.html, 18 November 2013

McConway KJ, Jones MC, Taylor PC (1999) Statistical modelling using Genstat. Arnold, London

Misselbrook TH, Smith KA, Johnson RA, Pain BF (2002) Slurry application techniques to reduce ammonia emissions: results of some UK field-scale experiments. Biosyst Eng 81:313-321. doi:10.1006/bioe. 2001.0017

Osterburg B, Isermeyer F, Lassen B, Röder N (2010) Impact of economic and political drivers on grassland use in the EU. Grassland Sci Eur 15:14-28

Pape A. (1995) Ziel-5b-Plan Landkreis Cuxhaven Forschungsprojekt Dauergrünlandnutung Teilprojekt 3: Minderung der Stickstoffemissionen auf Grünland. Final report (unpublished) 
Payne RW (2002) The guide to Genstat. Part 2: Statistics. VSN International, Oxford

Schröder JJ, Jansen AG, Hilhorst GJ (2005) Long-term nitrogen supply from cattle slurry. Soil Use Manag 21:196-204. doi:10.1111/j.14752743.2005.tb00125.x

Schröder JJ, Assinck FBT, Uenk D, Velthof GL (2010) Nitrate leaching from cut grassland as affected by the substitution of slurry with nitrogen mineral fertilizer on two soil types. Grass Forage Sci 65:49-57. doi:10.1111/j.1365-2494.2009. 00719.x

Smit HJ, Metzger MJ, Ewert F (2008) Spatial distribution of grassland productivity and land use in Europe. Agric Syst 98:208-219. doi:10. 1016/j.agsy.2008.07.004

Smith KA, Beckwith CP, Chalmers AG, Jackson DR (2002) Nitrate leaching following autumn and winter application of animal manures to grassland. Soil Use Manag 18:428-434. doi:10.1079/ SUM2002156

Stout WL, Weaver SR, Gburek WJ, Folmar GJ, Schnabel RR (2000) Water quality implications of dairy slurry applied to cut pastures in the northeast USA. Soil Use Manag 16:189-193. doi:10.1111/j. 1475-2743.2000.tb00191.x

Wachendorf M, Büchter M, Trott H, Taube F (2004) Performance and environmental effects of forage production on sandy soils. Grass Forage Sci 59:56-68. doi:10.1111/j.1365-2494.2004.00401.x

Webb J, Pain B, Bittman S, Morgan J (2010) The impacts of manure application methods on emissions of ammonia, nitrous oxide and on crop response - a review. Agric Ecosyst Environ 137:39-46. doi:10. 1016/j.agee.2010.01.001

Whitehead DC (1995) Grassland nitrogen. CAB International, Wallingford 